\title{
SEROPREVALENCE OF HEPATITIS C VIRUS IN THALASSEMIC PATIENTS
}

\author{
UDDIN MR ${ }^{1}$, RANA $\mathrm{M}^{2}$, ISLAM MMSUI ${ }^{3}$, BEGUM $\mathrm{F}^{4}$, SALIMULLAH ASM ${ }^{5}$, \\ AHSAN $K^{6}$, SARKER MN ${ }^{7}$, AHMED DS ${ }^{8}$, ROY PK ${ }^{9}$, RAIHAN ${ }^{9}$
}

\begin{abstract}
:
Hepatitis $C$ virus is one of the leading causes of liver disease and represents a major public health problem. It is a common cause of cirrhosis and hepatocellular carcinoma (HCC) as well as the most common reason for liver transplantation. This cross sectional study was carried out during the period of April 2007 to April 2008 among thalassemic patients with history of multiple blood transfusion (>20 units). Total 200 thalassemic patients from Thalassemia Samity Hospital, Green Road, Bangladesh Thalassemia Foundation, Dhanmondi, and from Department of Transfusion Medicine, Bangabandhu Sheikh Mujib Medical University (BSMMU), Dhaka were included in the study.After taking detailed history and clinical examination, $0.3 \mathrm{ml}$ of venous blood was collected from each patient and tested for anti HCV by commercial kit. Positive cases were confirmed by ELISA method. Among 200 patients majority (68.5\%) were below age of 20 years with a male to female ratio of 1.7:1,16.5\% were found to have anti HCV positive. Anti HCV positivity increased with duration of exposure and number of blood transfusion., 22.9\% of patients who had duration of exposure for more than 10 years and $36.4 \%$ having blood transfusion more than 40 units were positive for anti $\mathrm{HCV}$.
\end{abstract}

Key words: Seroprevalence, hepatitis $C$ virus, thalassemia.

J Dhaka Med Coll. 2009; 18(2) : 115- 119

\section{Introduction:}

Hepatitis $\mathrm{C}$ virus (HCV) is an important human pathogen. It has high prevalence and worldwide burden and produces several grave consequences if persistent, infection like cirrhosis of liver, hepatocellular carcinoma, and end-stage liver disease necessitating liver transplantation. The incidence of all of these "complications are expected to rise in the near future. ${ }^{1,2} \mathrm{HCV}$ accounts for about $15 \%$ of acute viral hepatitis, $60-70 \%$ of chronic hepatitis, and up to $50 \%$ of cirrhosis, end- stage liver disease and liver cancer. ${ }^{3} \mathrm{~A}$ distinct and major characteristic of hepatitis $\mathrm{C}$ virus is its tendency to cause chronic liver disease. ${ }^{4}$ At least $75 \%$ of patients with acute hepatitis C ultimately develop chronic infection. At least $20 \%$ of patients with chronic hepatitis C develop cirrhosis usually after 10 to 20 years. After 20 to 40 years, a small percentage of patient with chronic liver disease develop liver cancer. ${ }^{5} \mathrm{HCV}$ infection is often silent, and clinical symptoms are absent or minimal unless the disease is severe or cirrhosis is diagnosed. ${ }^{6}$ There are different risk factors for acquiring $\mathrm{HCV}$ Infection. The transmission of HCV primarily occurs through exposure to infected blood and blood products. Blood transfusion, injectable drug abuse, occupational exposure in health care workers, hemodialysis, solid organ transplantation from an infected donor, highrisk sexual activity, and birth to an infected mother are the modes of tranmission. ${ }^{7}$ According to the Centers for Disease Controls and Prevention (CDC), the most common risk factors for acute $\mathrm{HCV}$ infection in the U.S. from 1991-1995 were high-risk drug abuse in parenteral route $(60 \%)$ and risky sexual

1. Assistant Professor, Department of Gastroenterology, Faridpur Medical College Hospital, Faridpur.

2. Assistant Professor Gastroenterology, Bogra Medical College Hospital, Bogra.

3. Department of Gastroenterology, BSMMU, Dhaka.

4. Assistant Professor, Department of Pharmacology, Ibrahim Medical College, Dhaka.

5. Department of gastroenterology, BSMMU, Dhaka.

6. Lecturer, Department of Pathology, DMC, Dhaka.

7. Indoor Medical officer,Upazilla Health Complex, Louhojong, Munshigonj.

8. Associate Professor, Department of Gastroenterology, BSMMU, Dhaka.

9. Professor, Department of Gastroenterology, BSMMU, Dhaka.

Correspondence : Dr. Md. Royes Uddin. 
behaviors (20\%). Other modes of transmission (occupational, hemodialysis, household and perinatal) accounted for approximately $10 \%$ of infection. 8

A potential risk factor can be identified in approximately $90 \%$ of persons infected with $\mathrm{HCV}$. In the remaining $10 \%$, no recognized source of infection can be identified, although most persons in this category associated with low socio-economic level. ${ }^{9}$ Risk for sexual transmission is rare and occurs in $<5 \%$ of those couples where one of the individual is infected with HCV. Mother to infant transmission of $\mathrm{HCV}$ is possible but uncommon, and occurred in $3-5 \%$ of babies born to $\mathrm{HCV}$ positive mothers. ${ }^{10} \mathrm{HCV}$ is endemic in most parts of the world, with an estimated overall prevalence of $3 \%$, representing approximately 170 million HCV-infected persons world-wide. ${ }^{11}$ The estimated figures are $0.3 \%$ in New Zealand and $4 \%$ in Combodia. ${ }^{12}$ However, there is considerable geographic variation in the incidence and prevalence of $\mathrm{HCV}$ infection. Much of the variability between regions can be explained by the frequency and extent to which different risk factors like injection drug use accounting for 60 to $80 \%{ }^{13}$, transfusions and transplants 5 to $13 \%{ }^{13}$, unsafe injections and other healthcare related procedures 2 to $18 \%$, occupational exposures 0 to $7 \%{ }^{14}$, perinatal transmission 0 to $40 \%{ }^{15}$ have been contributed to the transmission of HCV. â-thalassemia major patients are among the high risk groups for HCV infection due to repeated blood transfusion. In contrast to the low rate of $\mathrm{HCV}$ infection in healthy population, thalassemic patients reveal high prevalence of HCV infection because of repeated exposure to blood. Infections among these patients ranged from $11.1 \%$ to $63 \%$ in various studies ${ }^{16-18}$ and rate of infection in these patients correlate with the amount of blood transfused. Studies from Italy, Iran and Thailand showed a high prevalence of anti HCV antibody of $60 \%, 27.1 \%$ and $20.2 \%$ respectively. ${ }^{19}, 20-22$ Seroprevalence of anti$\mathrm{HCV}$ among thalassemic patients was $56.8 \%$ in Pakistan. ${ }^{23} \mathrm{~A}$ study from Bangladesh revealed that anti-HCV seropositivity was $12.5 \%$ in thalassemic children compared to $0.9 \%$ among age and sex matched control group. ${ }^{24}$ This study was conducted with the aim to find out anti-HCV sero-prevalence among thalassemic patients.

\section{Materials and Methods:}

This cross sectional study was carried out during the period of April 2007 to April 2008 among thalassemic patients with history of multiple blood transfusion (>20 units). Total 200 thalassemic patients were enrolled from Thalassemia Samity Hospital, Green Road, Bangladesh Thalassemia Foundation, Dhanmondi, and from Department of Transfusion Medicine, BSMMU, Dhaka. After taking informed written consent of the subjects all necessary information were recorded in a pre-designed structured questionnaire. After that $3.0 \mathrm{ml}$ of venous blood was collected in a sterile test tube aseptically by venipuncture with sterile disposable syringe. Blood was tested for anti HCV by commercial kit according to standard operating procedure of manufacturer's instruction (Anti HCV test done by Excel HCV rapid device, made in USA). ${ }^{25}$ Sensitivity of this method was found to be $99 \%$ with Specificity of 98.6\% ${ }^{25,26}$ All positive cases were confirmed by ELISA method. Statistical analysis was performed using SPSS program. Odds ratio and chi-square test were done to test the significance of the factors of study in relation with the seroprevalence of anti-HCV antibodies. Logistic regression analysis was applied to identify the risk factors. $\mathrm{p}<0.05$ was considered significant.

\section{Results:}

Out of 200 patients $33(16.5 \%)$ were anti HCV positive and 167 (83.5\%) were anti $\mathrm{HCV}$ negative (Fig-1)

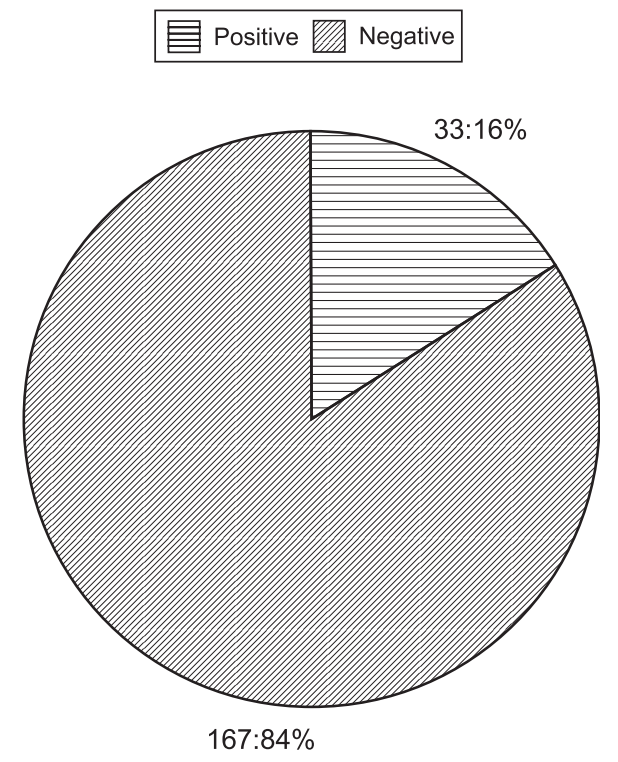

Fig-1: Distribution of patients according to anti HCV status. 
Among HCV positive individuals 21 (63.6\%) were male and 12 (36.4\%) were female and among HCV negative individuals 100 (66\%) were male and 57 (34\%) were female (Table-1). There is male predominance with a male to female ratio $1.7: 1$.

Table-I

Distribution of patients according sex.

\begin{tabular}{lcc}
\hline Anti HCV status & $\begin{array}{c}\text { Male No } \\
\text { of Patient (\%) }\end{array}$ & $\begin{array}{c}\text { Female No of } \\
\text { Patient (\%) }\end{array}$ \\
\hline Positive & $21(63.6)$ & $12(36.4)$ \\
Negative & $110(66)$ & $57(34)$ \\
\hline
\end{tabular}

Majority (68.5\%) of patients are within 20 years of age. Among $\mathrm{HCV}$ positive individuals, 25 $(76 \%)$ patients were in the age group of $<20$ years followed by $7(21 \%)$ in $21-30$ years and $1(3 \%)$ was $>30$ years of age. Among HCV negative individuals, $112(67 \%)$ patients were in $<20$ years of age, $40(24 \%)$ were in $21-30$ years and $15(9 \%)$ were in $>30$ years of age (Table-II)

Table-II

Distribution of patients according to age

\begin{tabular}{lcc}
\hline Age distribution & \multicolumn{2}{c}{ Anti HCV status } \\
\cline { 2 - 3 } & Positive & Negative \\
\hline$<20$ years $(\mathrm{n}=137)$ & $25(76 \%)$ & $112(67 \%)$ \\
21-30 years $(\mathrm{n}=47)$ & $7(21 \%)$ & $40(24 \%)$ \\
$>30$ years $(\mathrm{n}=16)$ & $1(3 \%)$ & $15(9 \%)$ \\
\hline
\end{tabular}

Among 200 patients, $84(42 \%)$ individuals were in middle socioeconomic class followed by 64 $(32 \%)$ in lower and $52(26 \%)$ were in upper class. Of them 12(14.36\%), 15(23\%) and 6 (11.5\%) were HCV positive respectively Table-III

Table-III

Distribution of patients according to socioeconomic status

\begin{tabular}{lcr}
\hline Social class & \multicolumn{2}{c}{ Anti HCV status } \\
\cline { 2 - 3 } & Positive & Negative \\
\hline Upper class $(\mathrm{n}=52)$ & $6(11.5 \%)$ & $46(88.5 \%)$ \\
Middle class $(\mathrm{n}=84)$ & $12(14.3 \%)$ & $72(85.7 \%)$ \\
Lower class $(\mathrm{n}=64)$ & $15(23 \%)$ & $49(77 \%)$ \\
\hline
\end{tabular}

Duration of exposure to risk factors was also calculated and was correlated with seropositivity of HCV. Out of 200 patient 88 (44\%) had 5-10 years of exposure of them 14 (16\%) were anti HCV positive, 70 (35\%) patient had $>10$ years exposure of them $16(22.8 \%)$ were anti HCV positive and $42(21 \%)$ had $<5$ years of exposure of them only $3(7.1 \%)$ were anti HCV positive (Table-IV).

\section{Table-IV}

Distribution of patients according to duration of exposure to risk factors

\begin{tabular}{lcr}
\hline Duration of exposure & \multicolumn{2}{c}{ Anti HCV status } \\
\cline { 2 - 3 } & Positive & Negative \\
\hline$<5$ years $(\mathrm{n}=42)$ & $3(7.1 \%)$ & $39(92.9 \%)$ \\
5-10 years $(\mathrm{n}=88)$ & $14(16 \%)$ & $74(84 \%)$ \\
$>10$ years $(\mathrm{n}=70)$ & $16(22.9 \%)$ & $54(77.1 \%)$ \\
\hline
\end{tabular}

In this study, populations were also distributed according to number of blood transfusion. Total $55(27.5 \%)$ patients received 20-30 units blood transfusion of them only $4(7.3 \%)$ were anti HCV positive, $112(56 \%)$ received 31-40 units blood transfusion of them $17(15.2 \%)$ were anti $\mathrm{HCV}$ positive and $33(16.5 \%)$ received $>40$ units blood transfusion of them 12(36.4\%) were anti HCV positive (Table-V)

\section{Table-V}

Distribution of patients according to number of blood transfusion

\begin{tabular}{lcr}
\hline Number of blood & \multicolumn{2}{c}{ Anti HCV status } \\
\cline { 2 - 3 } transfusion & Positive & Negative \\
\hline $20-30$ units $(n=55)$ & $4(7.3 \%)$ & $51(92.7 \%)$ \\
$31-40$ units $(n=112)$ & $17(15.2 \%)$ & $95(84.8 \%)$ \\
$>40$ units $(n=33)$ & $12(36.4 \%)$ & $21(63.6 \%)$ \\
\hline
\end{tabular}

$P$ value $=0.069$

On clinical examination, out of 200 patients all (100\%) had jaundice and hepatomegaly, 198 $(99 \%)$ patients had splenomegaly, $15(7.5 \%)$ had oedema, 7 (3.5\%) had clubbing. Spider nevi, palmar erythema, gynaecomastia, testicular atrophy, engorged abdominal vein, and ascities were not found in any individual.

\section{Discussion:}

Hepatitis $\mathrm{C}$ virus infection is a major cause of liver related morbidity and mortality and 
represents a major public health problem world wide. $\mathrm{HCV}$ infection is more notorious than hepatitis B virus infection (HBV) because of greater risk of chronicity and other sequelae of liver disease like chronic hepatitis, cirrhosis of liver and heaptocellular carcinoma. Its prevalence is lower than hepatitis B virus. The overall prevalence of $\mathrm{HCV}$ infection is $1 \%$ to $2 \%$ in most countries but the distribution of HCV varies considerably among different populations. ${ }^{8} \mathrm{HCV}$ is most frequently transmitted by percutaneous exposure to infected blood or blood derived body fluids and very high rates of $\mathrm{HCV}$ infection are found among persons exposed to HCV through these routes. HCV prevalence rate in USA is about $1.8 \%{ }^{13}$, in Africa it is $5.3 \%$. Mediterranean region $4.6 \%$, Western Pacific region $3.9 \%$, South East Asia 2.13\% and in Europe 1.03\%. ${ }^{11}$ In Pakistan, among voluntary blood donors anti $\mathrm{HCV}$ antibody positivity ranges from $0.44 \%$ to $1.18 \%$ and among health care workers is $6 \% .{ }^{27}$ In our neighboring country India, anti $\mathrm{HCV}$ positivity among voluntary blood donors ranges from 1.5 to $1.78 \%$ and among healthcare workers $4 \%^{28}$. There are few studies on seroprevalence of hepatitis $\mathrm{C}$ virus infection in Bangladesh. Studies done by Laura Gibney et al. ${ }^{29}$ in a population of Bangladeshi trucking industry by Shirin $\mathrm{T}$ et al ${ }^{30}$ among injectable and non injectable drug abuse, and by Khan $\mathrm{M}$ et al., ${ }^{31}$ in professional and non professional blood donors were < $1 \%, 24.8 \%, 5.8 \%, 1.2 \%$ and $0.0 \%$ respectively. In this study, prevalence of hepatitis $\mathrm{C}$ virus was found to be $16.5 \%$ out of 200 thalassemic patients. Previous study from Bangladesh on thalassemic patients reported the anti HCV seropositivity to be $12.5 \%{ }^{24}$. The prevalence of anti HCV positivity among thalasemics from India varied from 19\% $68 \%{ }^{32}$ Studies from Pakistan by Shah et al. $(2005)^{23}$ reported a much higher prevalence of $56.8 \%$. Prevalence of $20.0 \%$ and $60 \%$ were reported from Thailand and Italy respectively. ${ }^{20}$, 22 This wide variability among the prevalence reported in different studies is because of different sensitivity and specificity of the test used, different anti HCV prevalence in donor populations and differing donor selection criteria. ${ }^{33}$

\section{Conclusion:}

From this study it was evident that, majority $(68.5 \%)$ of patients were below 20 years of age and there is male preponderance with a male to female ratio $1.7: 1$. Out of 200 thalassemic patients $16.5 \%$ were found anti HCV positive. Anti HCV positivity increased with duration of exposure and number of blood transfusion. It was found that $22.9 \%$ of patients who had duration of exposure for more than 10 years and $36.4 \%$ who had history of blood transfusion for more than 40 units were positive for anti $\mathrm{HCV}$. It is difficult to comment on risk factors in this small population. To get dependable conclusion regarding prevalence of $\mathrm{HCV}$, further extensive studies with larger sample size should be carried out.

\section{References:}

1. E1-Serag HB, Mason AC: Rising incidence of hepatocellular carcinoma in the United Sates. N Engl J Med 1999; 340: 745.

2. Davis GL, Albright JE, Cook SF, Rosenberg DM. Projecting future complications of chronic hepatitis $\mathrm{C}$ in the United States. Liver Transpl. 2003; 9: 331 .

3. De Mitri MS, Poussin k, Baccarini P, Pontisso P, Paterlinni P. HCV associated liver cancer without cirrhosis. Lancet 1995; 345:413-415.

4. Estahen R. Epidemiology of Hepatitis C virus Infection. J Hepatol 1993; 17(suppl 3); 67-71.

5. Denson Smith. Chronic Hepatitis C: Current disease management. 2005.http:/digestive.niddh. govlddiseaseslpubslchYOnichepclindex. htm

6. Hoofnagle J, Di Biscigle AM. The treatment of chronic viral hepatitis. $N$ Engl $J$ Med 1997;336:347-353.

7. Stephen L. Chen and Timothy R. Morgan. The natural history of Hepatitis $\mathrm{C}$ virus Infection. Int J Med Sci 2006; 3(2): 47-52

8. Wasley A, Alter MJ. Epidemiology of hepatitis C: Geographic difference and temporal trends. Semm Liver Dis 2000; 20: 1-13.

9. Alter MJ. The epidemiology of Acute and Chronic Hepatitis C. Clinic Liver Dis 1997; 1(3): 559-68.

10. Poynard T, Yuen MF, Ratzui V, Lai CL. Viral hepatitis C. Lancet 2003; 362:2095-2100.

11. WHO. Global surveillance and control of Hepatitis C. Report of a WHO consultation organized in collaboration with the viral hepatitis prevention board, Antwerp, Belgium. J Viral Hepat 1999; 6:35-47. 
12. Kao JH and Chen DS. Transmission of hepatitis $\mathrm{C}$ virus in Asia. Past and present perspectives../ (jitstrocntcrol Hepatol 2000; 15(suppl):83-90.

13. Alter MJ. The epidemiology of Acute and Chronic Hepatitis C. Clinic Liver Dis 1997; 1(3): 559-68.

14. Lodi G, Portar SR, Teo C, Scully C. Prevalence of HCV infection in Health Care Workers of UK dental hospital. Dental J 1997; 183: 329-332.

15. Aizaki H, Saito A, Kushakawa I. Mother to child transmission of hepatitis $\mathrm{C}$ virus variants with an insertional mutation in its hyper variable region. J Hepatol 1996; 25:608-613.

16. DeMont A, Lembert M. Prevalence of markers for human immunodeficiency virus type 1 and 2 human $\mathrm{T}$ lymphotropic virus type-1, cytomegalo virus and hepatitis $B$ and $C$ virus in multiple transfused thalassemia patients. Transfusion. 1992; 32: 502-12.

17. Reddy GA, Dakshinamurathy KV, Neelaprasad $\mathrm{P}$, Gangadhar T, Laxmi V. Prevalence of HBV and $\mathrm{HCV}$ dual infections in patients on hemodialysis. Indian J Med Microbiol 2005; 23: 41-43.

18. Aroldi A, Latnpertico P, Montagnino G, Passarini $\mathrm{P}$, et al. Natural history of hepatitis $\mathrm{B}$ and $\mathrm{C}$ in renal allograft recipients. Transplantation 2005; 79: 1132-1136.

19. Fetelson M, Lega L, Guo J. Pathogenesis of posttransfusion viral hepatitis in children with âthalassemia. Hepatology 1994; 19(3): 558-68.

20. Wanchai W, Pairoj L, Sirangkapracha P, Leowattana W. Prevalence and clinical significance of hepatitis $\mathrm{C}$ virus infection in Thai patients with thalassemia. Int. J Hematol, 2003; 78(4): 374-378.

21. Saberi-Firoozii M, Yasdankhah S, Karbasi HT. Anti HCV seropositivity among multiple transfused patients with beta thalassemia major in Southern Iran. Inr J Med Sci , 1996; 21(1\&2): 59.

22. Emanuele Angelucci. Antibodies to Hepatitis C virus in Thalassemia. Haematologica, 1994; 79: 353-355.

23. Shah SMA, Khan MT, Ullah Z, Ashfaq NY. Prevalence of hepatitis $\mathrm{B}$ and $\mathrm{C}$ virus infection in multiple transfused thalassemic patients in North West Frontier Province, Pak J Med Sci. 2005; 21: 281-84.

24. Mollah AH, Nahar N, Siddique A, Anwar SK, Hassan T, Alam MG, Common transfusion transmitted infectious agents among thalassaemic children in Bangladesh. J Health Popul Nutr 2003; 21 (1):67-71.

25. Van der Poel, C.L., H.T.M. Cuypers, H.W. Reesink, and P.N. Lelie. Confirmation of hepatitis $\mathrm{C}$ virus infection by new four-antigen recombinant immunoblot assay. Lancet 1991; 337: 317.

26. Wilber, J.C. Development and use of laboratory tests for hepatitis $\mathrm{C}$ infection: a review $\mathrm{J}$ Clin Immunoassay 1993; 26: 204.

27. Mujeeb AS, Amir K, Mehmood K. Seroprevalence of HBV, HCV, and HIV infections among college going first time volunteer blood donors. J Pak Med Assoc 2000; 50(8):269-270.

28. Fetelson M, Lega L, Guo J. Pathogenesis of posttransfusion viral hepatitis in children with âthalassemia. Hepatology 1994; 19(3): 558-68.

29. Laura Gibney, Saquib N, Metzger J, Chowdhury P, Siddiqui MA, Hassan MS. Human immunodeficiency virus, hepatitis $\mathrm{B}$ and $\mathrm{C}$ in Bangladesh's trucking industry prevalence and risk factors. Int $\mathrm{J}$ Epidemiol 2001; 30: 878-884.

30. Shirin T, Ahmed T, Iqbal A, Islam M, Islam MN. Prevalence and risk factors of Hepatitis B, Hepatitis $\mathrm{C}$ and human immunodeficiency virus infection among drug addicts in Bangladesh. $\mathrm{J}$ Health Popul Nutr. 2000; 18 (3): 145-50.

31. Khan M, Husain M, Yano M. Comparison of seroepidemiology of hepatitis $\mathrm{C}$ in blood donors between Bangladesh and Japan. Gaslroenierologiu Japomca 1993; 28(suppl 15):2831 .

32. Chowdhury A, Santra A, Chaudhuri S, et al. Hepatitis $C$ virus infection in the general population: A community based study in West Bengal India. Hepatolog. 2003; 37(4):802-809.

33. Mishra D and Pensi T. Transfusion As hepatitis $\mathrm{C}$ in multitransfused thalassemic children. Indian Paedtr. 2004; 41: 28 